\title{
The current occurrence, habitat and historical change in the distribution range of an endemic tiger beetle species Cicindela (Ifasina) willeyi Horn (Coleoptera: Cicindelidae) of Sri Lanka
}

\author{
Chandima Dangalle ${ }^{1}$, Nirmalie Pallewatta ${ }^{2} \&$ Alfried Vogler $^{3}$ \\ 1,2 Department of Zoology, Faculty of Science, University of Colombo, Colombo 03 , Sri Lanka \\ ${ }^{3}$ Department of Entomology, The Natural History Museum, London SW7 5BD, United Kingdom \\ Email: ${ }^{1}$ cddangalle@yahoo.com (corresponding author), ${ }^{2}$ nirmalip@yahoo.com, ${ }^{3}$ a.vogler@nhm.ac.uk
}

\author{
Date of publication (online): 26 February 2011 \\ Date of publication (print): 26 February 2011 \\ ISSN 0974-7907 (online) | 0974-7893 (print) \\ Editor: K.A. Subramanian

\section{Manuscript details:} \\ Ms \# 02501 \\ Received 02 July 2010 \\ Final received 29 December 2010 \\ Finally accepted 05 January 2011
}

Citation: Dangalle, C., N. Pallewatta \& A. Vogler (2011). The current occurrence, habitat and historical change in the distribution range of an endemic tiger beetle species Cicindela (Ifasina) willeyi Horn (Coleoptera: Cicindelidae) of Sri Lanka. Journal of Threatened Taxa 3(2): 1493-1505.

Copyright: (C) Chandima Dangalle, Nirmalie Pallewatta \& Alfried Vogler 2011. Creative Commons Attribution 3.0 Unported License. JoTT allows unrestricted use of this article in any medium for non-profit purposes, reproduction and distribution by providing adequate credit to the authors and the source of publication.

Author Details, Acknowledments: see end of this article.

Author contribution: $C D$ conducted field studies in Sri Lanka and laboratory work in the Natural History Museum, London, U.K. She contributed towards research design and methodology and writing of the paper. NP contributed towards formulating the initial concept, research design and methodology and writing of the paper. AV contributed by formulating the initial concept and molecular sequencing methodology and analyses.
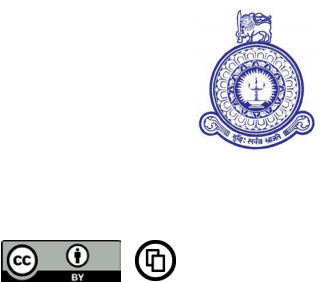

OPEN ACCESS | FREE DOWNLOAD
Abstract: The current occurrence, habitat and historical change in distributional range are studied for an endemic tiger beetle species, Cicindela (Ifasina) willeyi Horn of Sri Lanka. At present, the species is only recorded from Maha Oya (Dehi Owita) and Handapangoda, and is absent from the locations where it previously occurred. The current habitat of the species is explained using abiotic environmental factors of the climate and soil recorded using standard methods. Morphology of the species is described by studying specimens using identification keys for the genus and comparing with specimens available at the National Museum of Colombo, Sri Lanka. The DNA barcode of the species is elucidated using the mitochondrial $\mathrm{CO} 1$ gene sequence of eight specimens of Cicindela (Ifasina) willeyi. The study suggests that Maha Oya (Dehi Owita) and Handapangoda are suitable habitats. However, its presence in only two locations and its absence from locations where it previously occurred highlights the need for conserving the natural habitats at Maha Oya (Dehi Owita) and Handapangoda, and the necessity of further studies of this kind.

Keywords: Conservation, DNA barcode, habitat preferences, taxonomy, tiger beetles.

\section{INTRODUCTION}

Tiger Beetles (Coleoptera: Cicindelidae) are a group of attractive, fastflying and fast-running insect predators that occur in many diverse habitats around the world (Pearson \& Cassola 2007). The ease with which most species can be found and identified in the field, their habitat specificity and their value as indicators of habitat health and biodiversity have generated considerable interest among amateurs and professional biologists alike (Pearson \& Cassola 2007). As a result, a total of 2,559 species have been described world wide since the first eight cicindelid species were identified by Carl Von Linné in the $18^{\text {th }}$ century (Pearson \& Cassola 2005). Most tiger beetle species (29\% of described species) are found in the Oriental (Indo-Malaysian) region of the world, while northeastern India has the highest recorded number of species in a small area which is an $80 \mathrm{~km}$ stretch between Siliguri and Darjeeling of West Bengal (Pearson 1988; Pearson \& Cassola 2005). Sri Lanka is also attributed with a high number of cicindelid species and ranks amongst the top 30 countries of the world with the highest number of species (Cassola \& Pearson 2000).

The existing literature (Tennent 1860; Horn 1904; Fowler 1912; Naviaux 1984; Acciavatti \& Pearson 1989), and collections available at the National Museum of Colombo and Natural History Museum of London, documents 54 species of tiger beetles from Sri Lanka belonging to five genera (Table 1), Cicindela, Tricondyla, Derocrania, 
Table 1. The Cicindelidae of Sri Lanka according to the existing literature

\begin{tabular}{|c|c|c|c|}
\hline & Genus: Subgenus & Species & Locality \\
\hline 1 & Collyris & Collyris dohrni Chaudoir, 1860 & Trincomalee, Haldummulle, Paranthan, Odduchuddan, Colombo \\
\hline 2 & Neocollyris & Neocollyris planifrons Horn, 1905 & Wellawaya \\
\hline 3 & & Neocollyris punctatella Chaudoir, 1864 & Balangoda \\
\hline 4 & & Neocollyris saundersi Chaudoir, 1864 & Kanthalai, Bandarawela, Kandy, Wellawaya, Trincomalee, Peradeniya \\
\hline 5 & & Neocollyris crassicornis Dejean, 1825 & Elephant Pass \\
\hline 6 & & Neocollyris plicaticollis Chaudoir, 1864 & Urugalla \\
\hline 7 & & Neocollyris andrewesi Horn, 1894 & \\
\hline 8 & & Neocollyris ceylonica Chaudoir, 1864 & Bogawantalawa \\
\hline 9 & Tricondyla & Tricondyla coriacea Chevrolat, 1841 & $\begin{array}{l}\text { Kanthalai, Horowpatana, Urugalla, Mankulam, Trincomalee, } \\
\text { Neerodumunai, Olumadu, Kekirawa, Palatupana, Chilaw, Ella, } \\
\text { Wellawaya, Kandy, Tirukkovil }\end{array}$ \\
\hline 10 & & Tricondyla granulifera Motschulsky, 1857 & Urugalla, Homagama, Haragam, Nalanda, Kandy \\
\hline 11 & & Tricondyla nigripalpis Horn, 1894 & Kongawella, Central Ceylon \\
\hline 12 & Derocrania & Derocrania agnes Horn, 1905 & \\
\hline 13 & & Derocrania nietneri Motschulsky, 1859 & $\begin{array}{l}\text { Urugalla, Rakwana, Bulutota, Balangoda, Bandarawela, } \\
\text { Bogawantalawa, Nuwara Eliya, Nalanda, Kandy }\end{array}$ \\
\hline 14 & & Derocrania fusiformis Horn, 1904 & \\
\hline 15 & & Derocrania gibbiceps Chaudoir, 1860 & Urugalla, Nalanda, Central Ceylon \\
\hline 16 & & Derocrania concinna Chaudoir, 1860 & Urugalla, Kandy, Balangoda, Rakwana, Nalanda, Puttalam \\
\hline 17 & & Derocrania schaumi Horn, 1892 & Trincomalee, Hambantota, Kandy, Kekirawa \\
\hline 18 & & Derocrania halyi Horn, 1900 & Anuradhapura, Pankulam, Kanthalai, Trincomalee, Puttalam \\
\hline 19 & & Derocrania scitiscabra Walker, 1859 & $\begin{array}{l}\text { Urugalla, Horowpatana, Trincomalee, Badulla, Tamblegam, } \\
\text { Galgamuwa, Uva province, Belihul Oya, Haldummulla, Sigiriya, } \\
\text { Nalanda, Kandy }\end{array}$ \\
\hline 20 & & Derocrania nematodes Schaum, 1863 & Bogawantalawa, Central Ceylon \\
\hline 21 & Cicindela: Ifasina & Cicindela willeyi Horn, 1904 & Central Province, Labugama \\
\hline 22 & & Cicindela waterhousei Horn, 1900 & Labugama, Kitulgala, Karawanella, Avissawella \\
\hline 23 & & Cicindela dormeri Horn, 1898 & $\begin{array}{l}\text { Kitulgala, Labugama, Kandy, Peradeniya, Haragama, Udawattakele } \\
\text { Sanctuary }\end{array}$ \\
\hline 24 & & Cicindela ganglbaueri Horn, 1892 & Rakwana, Ratnapura, Kanneliya, Labugama \\
\hline 25 & & Cicindela henryi Horn, 1925 & Minneriya, Horowpatana, Kala Oya, Kataragama \\
\hline 26 & & Cicindela labioaenea Horn, 1892 & $\begin{array}{l}\text { Wariyapola, Kandy, Horowpatana, Kotte, Battaramulla, Kanneliya } \\
\text { forest, Kitulgala, Udugama, Wellawaya, Miyanapalawa, Labugama, } \\
\text { Puttalam, Negombo, Yatiyantota, Peradeniya, Nalanda, Weligama, } \\
\text { Hatton, Karawanella, Avissawella, Matugama, Opanake, Ratnapura, } \\
\text { Kegalla, Weddagala, Nittambuwa, Kurunegala, Udawattakele, } \\
\text { Pompakele, Ambalamahena }\end{array}$ \\
\hline 27 & & Cicindela nietneri Horn, 1894 & Kurunegala \\
\hline 28 & Oligoma & Cicindela lacunosa Putzeys, 1875 & $\begin{array}{l}\text { Andankulam, Horowpatana, Mullativu, Koggala, Habarana, } \\
\text { Minneriya, Hatton, Wellawaya, Wavuniya, Wilpattu National } \\
\text { Park, Anuradhapura, Kandy, Puttalam, Kataragama, Lahugala, } \\
\text { Tissamaharama, Kurunegala, Kala Oya }\end{array}$ \\
\hline 29 & & Cicindela paradoxa Horn, 1892 & $\begin{array}{l}\text { Puttalam, Matale, Negombo, Colombo Museum Garden, Weligama, } \\
\text { Hendala, Kitulgala, Matugama, Weddagala, Yatiyantota }\end{array}$ \\
\hline 30 & Jansenia & Cicindela corticata Putzeys, 1875 & $\begin{array}{l}\text { Andankulam, Koggala, Minneriya, Habarana, Hambantota, } \\
\text { Peradeniya, Kataragama, Uggalkaltota, Wavulpane, Maduvanwala, } \\
\text { Angunakolapelessa, Kala Oya }\end{array}$ \\
\hline 31 & & Cicindela westermanni Schaum, 1861 & \\
\hline 32 & & Cicindela laeticolor Horn, 1904 & Trincomalee, Hambantota \\
\hline
\end{tabular}




\begin{tabular}{|c|c|c|c|}
\hline & Genus: Subgenus & Species & Locality \\
\hline 33 & & Cicindela cirrihidia & Cockmuttai, Jaffna, Anuradhapura, Wilpattu National Park \\
\hline 34 & & Cicindela stellata & Trincomalee \\
\hline 35 & Myriochile & Cicindela distinguenda Dejean, 1825 & $\begin{array}{l}\text { Elephant Pass, Hambantota, Anuradhapura, Puttalam, Padaviya, } \\
\text { Kilinochchi, Mannar }\end{array}$ \\
\hline 36 & & Cicindela undulata Dejean, 1825 & $\begin{array}{l}\text { Galgamuwa, Andankulam, Colombo, Tissamaharama, Puttalam, } \\
\text { Lahugala, Kala Oya }\end{array}$ \\
\hline 37 & Monelica & Cicindela fastidiosa Dejean, 1825 & $\begin{array}{l}\text { Mankulam, Andankulam, Koggala, Elephant Pass, Habarana, } \\
\text { Hambantota, Haldummulle, Eppawala, Trincomalee, Wilpattu } \\
\text { National Park, Anuradhapura, Tissamaharama, Puttalam, Lahugala, } \\
\text { Kala Oya }\end{array}$ \\
\hline 38 & Lophyridia & Cicindela angulata Fabricius, 1798 & $\begin{array}{l}\text { Mannar District, Pesalai, Talaimannar, Hendala, Anuradhapura, } \\
\text { Chilaw, Sigiriya, Kurunegala, Mahaweli ganga, Kalkudah, Puttalam, } \\
\text { Godakewela, Arugam Bay, Deduru Oya, Colombo, Yala }\end{array}$ \\
\hline 39 & & Cicindela cardoni Fleutiaux, 1890 & $\begin{array}{l}\text { Maduru Oya, Punani, Chilaw, Mahaweli Ganga, East Polonnaruwa, } \\
\text { Kurunegala, Kegalla }\end{array}$ \\
\hline 40 & Calochroa & Cicindela discrepans Walker, 1858 & $\begin{array}{l}\text { Wellawaya, Horowpatana, Kandy, Colombo, Habarana, Sigiriya, } \\
\text { Anuradhapura, Badulla, Hambantota, Kataragama, Nalanda, } \\
\text { Kitulgala, Kala Oya }\end{array}$ \\
\hline 41 & & $\begin{array}{l}\text { Cicindela haemorrhoidalis Wiedemann, } \\
1823\end{array}$ & $\begin{array}{l}\text { Horowpatana, Anuradhapura, Kataragama, Haragama, Eppawala, } \\
\text { Wellawaya, Sigiriya }\end{array}$ \\
\hline 42 & & Cicindela sexpunctata Fabricius, 1775 & Jaffna, Maha Oya, Sigiriya, Puttalam District, Wellawaya \\
\hline 43 & & $\begin{array}{l}\text { Cicindela aurovittata Audouin \& Brullé, } \\
1839\end{array}$ & Maha Oya, Puttalam, Mundal, Kalkudah, Deduru Oya \\
\hline 44 & & Cicindela lacrymans Schaum, 1863 & $\begin{array}{l}\text { Labugama, Kandy, Kelani Valley, Kottawa, Kanneliya, Ratnapura, } \\
\text { Udawattakele Sanctuary, Gilimale, Kitulgala }\end{array}$ \\
\hline 45 & Ancylia & Cicindela ceylonensis Horn, 1892 & Wellawaya, Pulmoddai, Moneragala, Trincomalee \\
\hline 46 & & Cicindela calligramma Schaum, 1861 & Puttalam District, Palugassegama \\
\hline 47 & & Cicindela diversa Horn, 1904 & Anuradhapura, Giritale, Mannar, Wilpattu National Park, Cockmuttai \\
\hline 48 & Lophyra & Cicindela fuliginosa Dejean, 1826 & \\
\hline 49 & & Cicindela catena Fabricius, 1775 & $\begin{array}{l}\text { Miyanapalawa, Colombo, Matale, Kandy, Hendala, Labugama, } \\
\text { Kitulgala, Bentota, Matugama, Kurunegala, Puttalam, Kala } \\
\text { Oya, Weddagala, Kataragama, Kandachchi, Aluthgama, Jaffna, } \\
\text { Dolosbage, Trincomalee, Hambantota }\end{array}$ \\
\hline 50 & Cosmodela & Cicindela aurulenta Fabricius, 1801 & \\
\hline 51 & Hypaetha & Cicindela quadrilineata Fabricius, 1781 & Marichchakkaddi, Colombo \\
\hline 52 & & Cicindela biramosa Fabricius, 1781 & $\begin{array}{l}\text { Mannar, Mount Lavinia, Colombo Trincomalee, Weligama, Delft, } \\
\text { Hendala, Kalutara, Nilaweli, Kalkudah, Pottuvil, Pesalai, Galle, Kelani } \\
\text { Valley }\end{array}$ \\
\hline 53 & Callytron & Cicindela limosa Saunders, 1834 & Puttalam, Iranativu, Chilaw \\
\hline 54 & Eugrapha & Cicindela singalensis Horn, 1911 & Hambantota \\
\hline
\end{tabular}

Collyris and Neocollyris. The majority of species are included in the genus Cicindela which consists of 13 subgenera, Ancylia, Calochroa, Lophyra, Lophyridia, Jansenia, Oligoma, Cosmodela, Eugrapha, Monelica, Myriochile, Hypaetha, Callytron and Ifasina (Table 1). Subgenus Ifasina is attributed with the highest number of species (7) out of which five species are endemic to the island.

We report in this paper the first recorded occurrence of an endemic tiger beetle species, Cicindela (Ifasina) willeyi, from two locations of Sri Lanka and the habitat preferences of the species.

\section{METHODS AND MATERIALS}

Tiger beetles were surveyed in 94 localities of Sri Lanka from May 2002 to December 2005 (Fig. 1, 


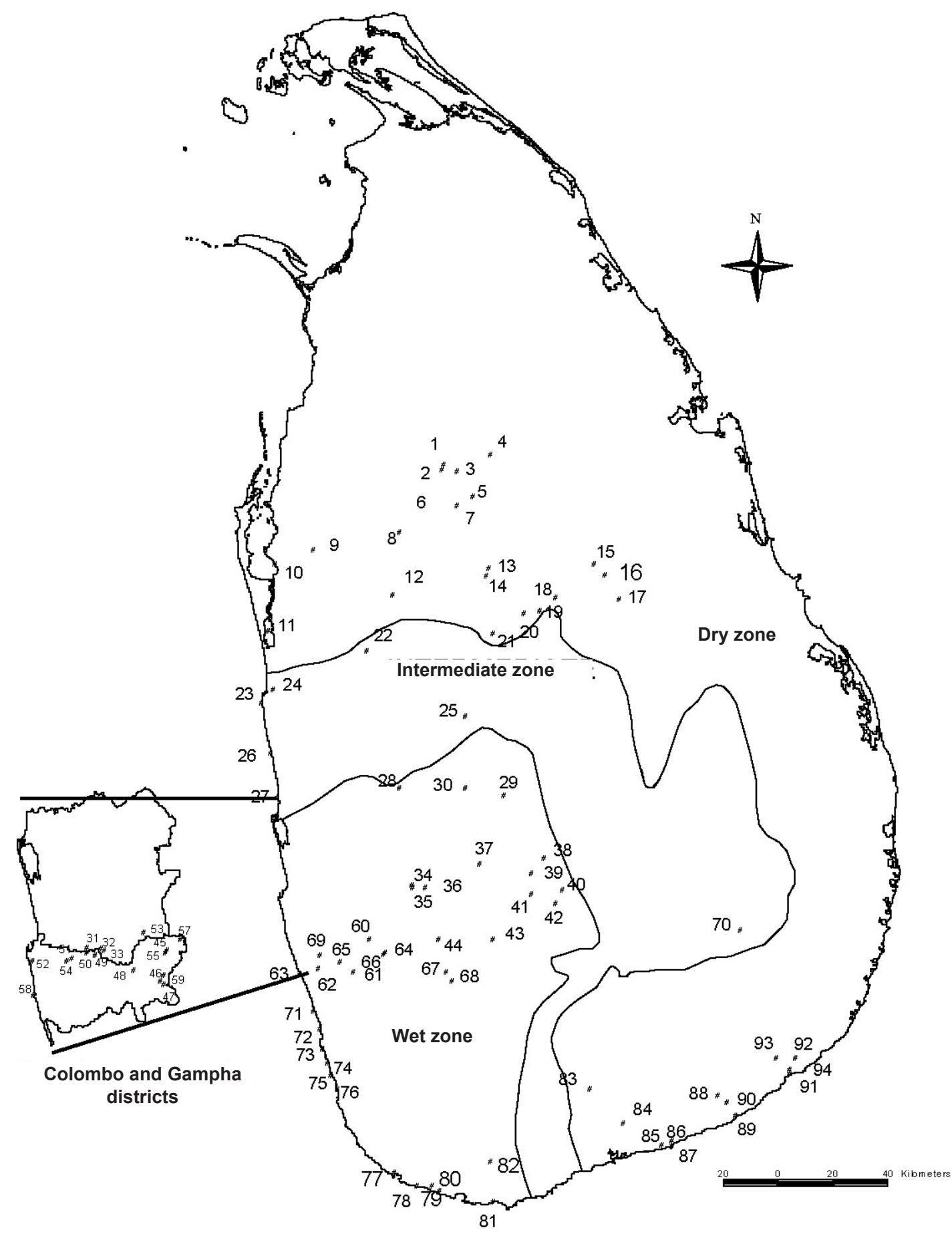

Figure 1. Localities of Sri Lanka surveyed for the occurrence of tiger beetles (Place names of localities are provided in Table 2)

Table 2). The localities for collecting tiger beetles were selected using information based on previous publications of cicindelid species of Sri Lanka and information based on the different habitat types of the family on a global scale.

Field studies were conducted at Maha Oya (Dehi
Owita) in August 2003 and 2004, and at Handapangoda in July 2003 and 2004.

Study Area: Maha Oya is a stream located at Dehi Owita (6 $57^{\prime} 91$ ' N \& 80 $16^{\prime} 44^{\prime \prime}$, elevation $6.7 \mathrm{~m}$ ) in the Kegalle District, Sabaragamuwa Province of Sri Lanka. It covers an area of $17 \mathrm{~km}^{2}$ and encompasses 
Table 2. Localities of Sri Lanka surveyed for the occurrence of tiger beetles

\begin{tabular}{|c|c|}
\hline $\begin{array}{l}\text { Location } \\
\text { Number }\end{array}$ & Place Name \\
\hline 1 & Abhaya Wewa, Anuradhapura \\
\hline 2 & Thisa Wewa, Anuradhapura \\
\hline 3 & Nuwara Wewa, Anuradhapura \\
\hline 4 & Mahakanadarawa Wewa, Anuradhapura \\
\hline 5 & Nachchaduwa Wewa, Anuradhapura \\
\hline 6 & Talawa Tank, Talawa \\
\hline 7 & Turuwila Wewa, Anuradhapura \\
\hline 8 & Rajangana Reservoir, Tambuttegama \\
\hline 9 & Tabbowa Wewa, Karuwalagaswewa \\
\hline 10 & Puttalam Lagoon, Puttalam \\
\hline 11 & Mundel Lake, Puttalam \\
\hline 12 & Kurundankulama Tank, Anuradhapura \\
\hline 13 & Kala Wewa, Anuradhapura \\
\hline 14 & Balalu Wewa, Anuradhapura \\
\hline 15 & Minneriya Wewa, Polonnaruwa \\
\hline 16 & Giritale Wewa, Polonnaruwa \\
\hline 17 & Parakrama Samudra, Polonnaruwa \\
\hline 18 & Sigiriya, Matale District \\
\hline 19 & Kandalama Tank, Dambulla \\
\hline 20 & Dambulu Oya, Dambulla \\
\hline 21 & Dewahuwa Wewa, Dambulla \\
\hline 22 & Magalla Tank, Nikaweratiya \\
\hline 23 & Chilaw Coast, Chilaw \\
\hline 24 & Deduru Oya, Halawatha \\
\hline 25 & Batalegoda Tank, Ibbagamuwa \\
\hline 26 & Marawila Coast, Marawila \\
\hline 27 & Porutota Coast, Negombo \\
\hline 28 & Ma Oya, Alawwa \\
\hline 29 & Meewatura, Peradeniya \\
\hline 30 & Ma Oya, Mawanella \\
\hline 31 & Biyagama, Gampaha \\
\hline 32 & Kimbulawila Wewa, Malwana \\
\hline 33 & Seethawaka River, Thalduwa \\
\hline 34 & Maha Oya Falls, Dehi Owita \\
\hline 35 & Maha Oya, Dehi Owita \\
\hline 36 & Kahanawita Falls, Dehi Owita \\
\hline 37 & We Oya, Yatiyantota \\
\hline 38 & Ramboda Falls, Ramboda \\
\hline 39 & Pundalu Oya, Talawakele \\
\hline 40 & Silver Falls, Nuwaraeliya \\
\hline 41 & Kotmale Oya, Talawakele \\
\hline 42 & Dessford Falls, Talawakele \\
\hline 43 & Adams Peak, Ratnapura \\
\hline 44 & Bopath Falls, Ratnapura \\
\hline 45 & Water Canal, Labugama \\
\hline 46 & Water Canal, Puwakpitiya \\
\hline 47 & Kumari Falls, Thummodara \\
\hline
\end{tabular}

\begin{tabular}{|c|c|}
\hline $\begin{array}{l}\text { Location } \\
\text { Number }\end{array}$ & Place Name \\
\hline 48 & Heen Ela, Waga \\
\hline 49 & Kelani Rriver, Kaduwela \\
\hline 50 & Kelani River, Kirielamulla \\
\hline 51 & Angoda, Colombo \\
\hline 52 & National Museum Garden, Colombo \\
\hline 53 & Kelani River, Malwana \\
\hline 54 & Pugoda Ferry, Kosgama \\
\hline 55 & Malabe, Colombo \\
\hline 56 & Ranwala Ferry, Awissawella \\
\hline 57 & Pahuru Wila, Malwana \\
\hline 58 & Aswathu Oya, Awissawella \\
\hline 59 & Mount Lavinia Beach \\
\hline 60 & Wak Oya, Thummodara \\
\hline 61 & Water Canal, Handapangoda \\
\hline 62 & Water Canal, Horana \\
\hline 63 & Mahabellana Ferry \\
\hline 64 & Thalpitiya, Wadduwa \\
\hline 65 & Nachchimale, Horana \\
\hline 66 & Kalu Ganga Bank, Horana \\
\hline 67 & Kalu Ganga, Ingiriya \\
\hline 68 & Gammanpila Tank, Bandaragama \\
\hline 69 & Katugasella Falls, Ratnapura \\
\hline 70 & Maragalakanda, Moneragala \\
\hline 71 & Irahandapana Falls, Ratnapura \\
\hline 72 & Katukurunda Coast, Kalutata \\
\hline 73 & Maggona Coast, Maggona \\
\hline 74 & Aluthgama Coast, Aluthgama \\
\hline 75 & Induruwa Coast, Induruwa \\
\hline 76 & Kosgoda Beach, Kosgoda \\
\hline 77 & Galle Harbour, Galle \\
\hline 78 & Morampitigoda Coast, Morampitigoda \\
\hline 79 & Habaraduwa Beach, Habaraduwa \\
\hline 80 & Kataluwa Coast, Koggala \\
\hline 81 & Matara Beach, Matara \\
\hline 82 & Enselwatta, Sinharaja \\
\hline 83 & Kollewa Dola, Sinharaja \\
\hline 84 & Chandrika Wewa, Embilipitiya \\
\hline 85 & Ridiyagama Wewa, Ambalantota \\
\hline 86 & Karagan Salterns, Hambantota \\
\hline 87 & Hambantota Salterns, Hambantota \\
\hline 88 & Hambantota Beach, Hambantota \\
\hline 89 & Tissa Wewa, Tissamaharama \\
\hline 90 & Kirinda Beach, Kirinda \\
\hline 91 & Yoda Wewa, Tissamaharama \\
\hline 92 & Menik Ganga, Kataragama \\
\hline 93 & Salterns, Yala \\
\hline 94 & Sellakataragama, Kataragama \\
\hline
\end{tabular}


the Grama Niladhari divisions of Dehi Owita, Debagama and Thimbiripola. The stream is a branch of the much larger Kelani River which starts from the Sri Pada Mountain range and flows in to the ocean at Colombo. The water of Maha Oya is slow flowing and runs parallel to a large sandy bank with $167 \mathrm{~m}$ elevation (Fig. 2 \& Image 1).

The stream at Handapangoda $\left(6^{0} 47^{\prime} 05 \mathrm{~N} \&\right.$ $80^{\circ} 08^{\prime} 03 \mathrm{E}$; elevation $23 \mathrm{~m}$ ) is located near a rubber estate in the Kalutara District, Western Province of Sri Lanka. It covers an area of $11 \mathrm{~km}^{2}$ and encompasses the Grama Niladhari divisions of Handapangoda, Arakawila, Menerigama and Kurana. It is a branch of Kalu Ganga, which is the second largest river of Sri Lanka and is restricted entirely to the wet zone of the country. The water of the stream is slow flowing and runs parallel to a narrow sandy bank that consists mostly of rocks (Fig. 2 \& Image 2).

Collection of Beetles: Four visits were made to each site for surveying adult tiger beetles. Three belts of land of 100 to $150 \mathrm{~m}$ were selected on the sandy bank of Maha Oya, while two belts were selected on the bank of Handapangoda. All sites were sampled over five hours each day between 1000 to $1400 \mathrm{hr}$.

Beetles were searched for in specific habitats and their immediate surroundings e.g. shrub area near the sandy sections of the stream, rocky substrata, pathways and trails. When encountered tiger beetles were rapidly counted at a given site using a hand tally counter (Wagtech, UK) and a sample was collected using a standard insect net. The number of beetles and the sex ratio of those that could be observed under field conditions and from collected specimens were recorded.

Specimens were collected and preserved in $96 \%$ ethanol and stored at $-20^{\circ} \mathrm{C}$ for subsequent identification.

Measuring Habitat Variables: The following habitat variables of the study sites were recorded.

(i) Weather variables: The ambient temperature, degree of solar radiation, relative humidity and wind speed of the habitat were recorded using a portable integrated weather station (Health EnviroMonitor, Davis Instrument Corp., Hayward, CA, USA) with optional sensors.

(ii) Soil characteristics: These included the soil group (determined by using the generalized soil map of Sri Lanka by Moorman \& Panabokke 1961);

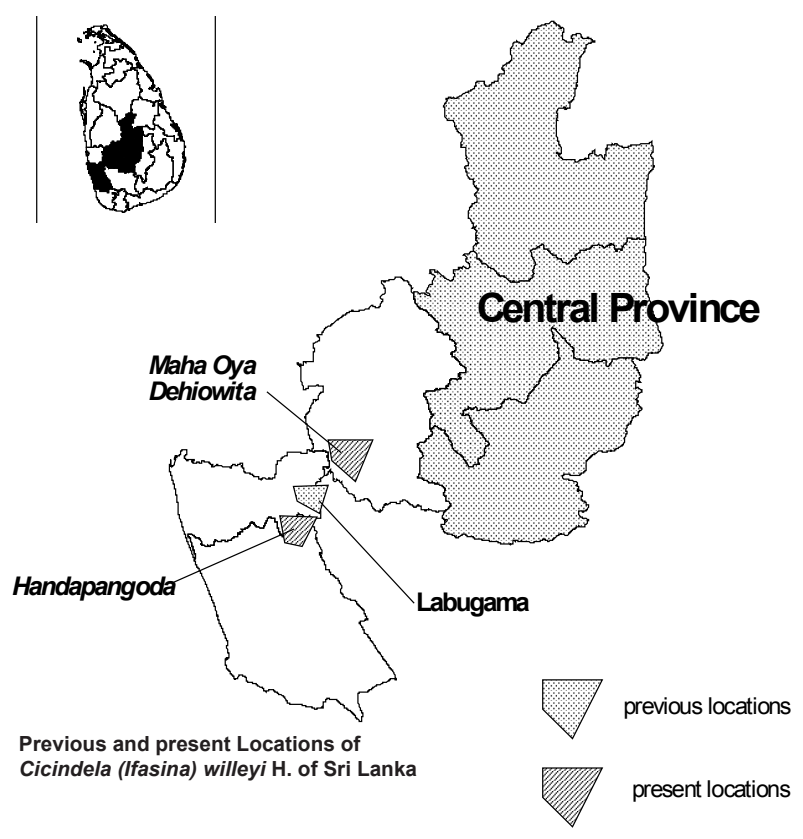

Figure 2. Study area at Maha Oya and Handapangoda with previous locations

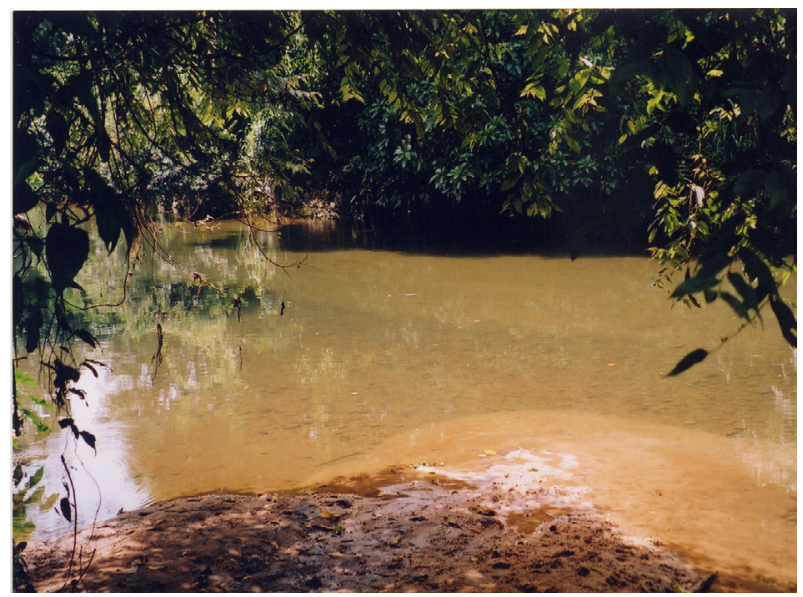

Image 1. Maha Oya (Dehi Owita)

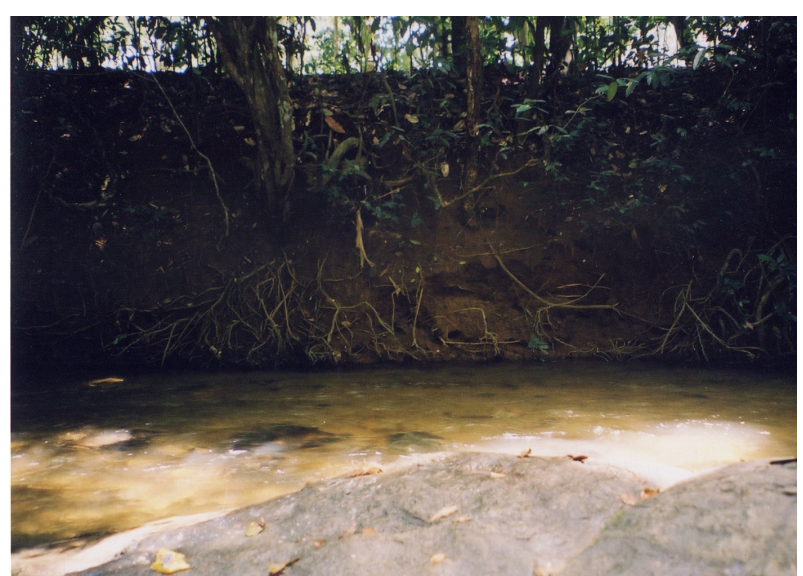

Image 2. Stream at Handapangoda 
soil type / texture (determined by the sedimentation technique using the "soil textural triangle" as the reference (Bierman 2007)); soil colour (measured by comparison with a Munsell soil colour chart); soil temperature (determined by using an insert soil thermometer (SG 680-10) ranging from -10 to $110^{\circ} \mathrm{C}$ ); soil $\mathrm{pH}$ (determined by using a portable soil $\mathrm{pH}$ meter (Westminster, No.259)); soil moisture (determined by selecting five random spots of a locality and collecting samples down to a depth of $10 \mathrm{~cm}$ and estimating the difference in weight before and after oven drying to 107 to $120{ }^{\circ} \mathrm{C}$ in the laboratory.); soil salinity (determined by a YSI model 30 hand-held salinity meter).

Determination of morphological characteristics of tiger beetles: Morphological characters important in identification and for the purpose of establishing characteristics of this species were also noted as follows.

(i) Body weight: Each beetle was weighed to the nearest $\mathrm{mg}$ on an analytical balance (Chyo JL180, Chyo Balance Corp., Japan).

(ii) Body length: Estimated by measuring the length from the frons of the head to the elytral apex when the head was in the normal feeding position. The spines on the caudal end of the elytra were disregarded. Measurements were taken using a dissecting microscope (Nikon Corporation SE., Japan) with the aid of an eyepiece graticule (Nikon, Tokyo, Japan) calibrated by an objective micrometer (Olympus, Japan).

Body lengths of beetles were categorized as follows, based on size classes relevant for this group of insects (Acciavatti \& Pearson 1989).

1. very small - less than $8 \mathrm{~mm}$

2. small -8 to $10 \mathrm{~mm}$

3. medium -10 to $15 \mathrm{~mm}$

4. large -15 to $20 \mathrm{~mm}$

5. very large - more than $20 \mathrm{~mm}$

(iii) Mandible length / chord: The distance from the articulation point of the left mandible to the tip were measured under a dissecting microscope (Nikon Corporation SE, Japan) with the aid of an eyepiece graticule (Nikon, Tokyo, Japan) calibrated by an objective micrometer (Olympus, Japan). Only specimens with undamaged or not noticeably worn mandibles were used (Pearson \& Juliano 1993; Satoh \& Hori 2004).

(iv) Other characters: In addition to the above characters the following features were also recorded for each specimen.

1. Colouration - Dorsal and ventral colouration of the body and its metallic or iridescent appearance was noted as was the colour of the elytral maculae, pits, eyes, antennae, mandibles, labrum and legs.

2. Number of rugae between eye and vertex.

3. Labrum - The shape of the labrum and the number of labral setae.

4. Distribution of setae on body.

5. Distribution of pits on body.

The above characters were observed under a photomicrographic attachment (Microflex AFX - DX, Nikon Corporation, Tokyo, Japan) which was also used in photographing each specimen (dorsal view, ventral view, lateral view, other important features). Additional photographs of species were also taken by using the computer software programme Auto Montage (facilitated with a SMC Pentax - FA macro camera) available at the entomology laboratory of the Natural History Museum, London.

Taxonomic keys of the Cicindela of the Indian subcontinent by Acciavatti \& Pearson (1989), descriptions of Horn, (1904) and Fowler (1912) were used to identify the species and confirmation of identification was done through comparisons with specimens available at the National Museum of Colombo.

DNA Sequencing: DNA analysis was carried out to determine the DNA barcode of the species. Eight specimens from the two known populations (Maha Oya and Handapangoda) were used for DNA extraction and sequencing. DNA was extracted from the abdominal region of the beetle using the DNeasy protocol (July 2003). Voucher specimens were deposited in the Entomology Collection of the Department of Zoology, University of Colombo.

A $~ 810$ bp region of the 3 ' end of the cytochrome oxidase 1 (CO1) gene was amplified using primers M202 (forward, 5' - CAA CAT TTA TTT TGA TTT TTT GG - 3', alias Jerry; Simon et al. 1994) and M70 (reverse, 5' - TCC ATT GCA CTA ATC TGC CAT ATT A - 3', alias Pat; Simon et al. 1994).

Standard PCR amplifications included $5 \mu$ of $\mathrm{NH}_{4}$ buffer, $0.5 \mu 1$ of each dNTP, $1 \mu 1$ of each primer, $0.1 \mu 1$ of TAQ polymerase and $2.5 \mu \mathrm{l}$ of $\mathrm{MgCl}_{2}$ in a $50 \mu \mathrm{l}$ reaction volume. PCR amplifications were carried out on a GeneAmp PCR System 9700 thermal cycler 
(Applied Biosystems, California, USA) for one cycle of $\left(94^{\circ} \mathrm{C}, 2.5\right.$ mins.; $47^{\circ} \mathrm{C}, 0.5$ mins.; $72^{\circ} \mathrm{C}, 11$ mins.; $\left.4^{0} \mathrm{C}, \alpha\right)$ for 40 cycles. The PCR products were purified using the UltraClean PCR clean-up DNA purification kit (MoBio Laboratories Inc., Carlsbad, CA, USA) according to the manufacturer's protocol.

Sequencing was performed for $10 \mu 1$ of cleaned PCR product using the ABI Prism Big Dye Terminator Cycle sequencing kit (PE Applied Biosystems, Foster City, CA, USA). PCR primers were used as sequencing primers and each fragment was sequenced on both strands. The reaction products were purified by ethanol precipitation and sequenced on ABI 373 (version 3.0) automated DNA sequencer. Sequence files were edited using SEQUED version 1.0.3 (Applied Biosystems) and a consensus of bidirectional sequencing was determined.

\section{RESULTS}

Cicindela (Ifasina) willeyi $\mathrm{H}$. was the only tiger beetle species observed at Maha Oya (Dehi Owita) and Handapangoda. Fifty beetles of Cicindela (Ifasina) willeyi. were observed from Maha Oya (Dehi Owita) and five beetles were collected for morphometric and morphological characterization. Ten specimens of the species were recorded from Handapangoda and three were collected for characterization.

Taxonomy of Cicindela (Ifasina) willeyi Horn, 1904: The description given in Horn (1904), Fowler (1912) and Acciavatti \& Pearson (1989) and the specimens available at the National Museum,

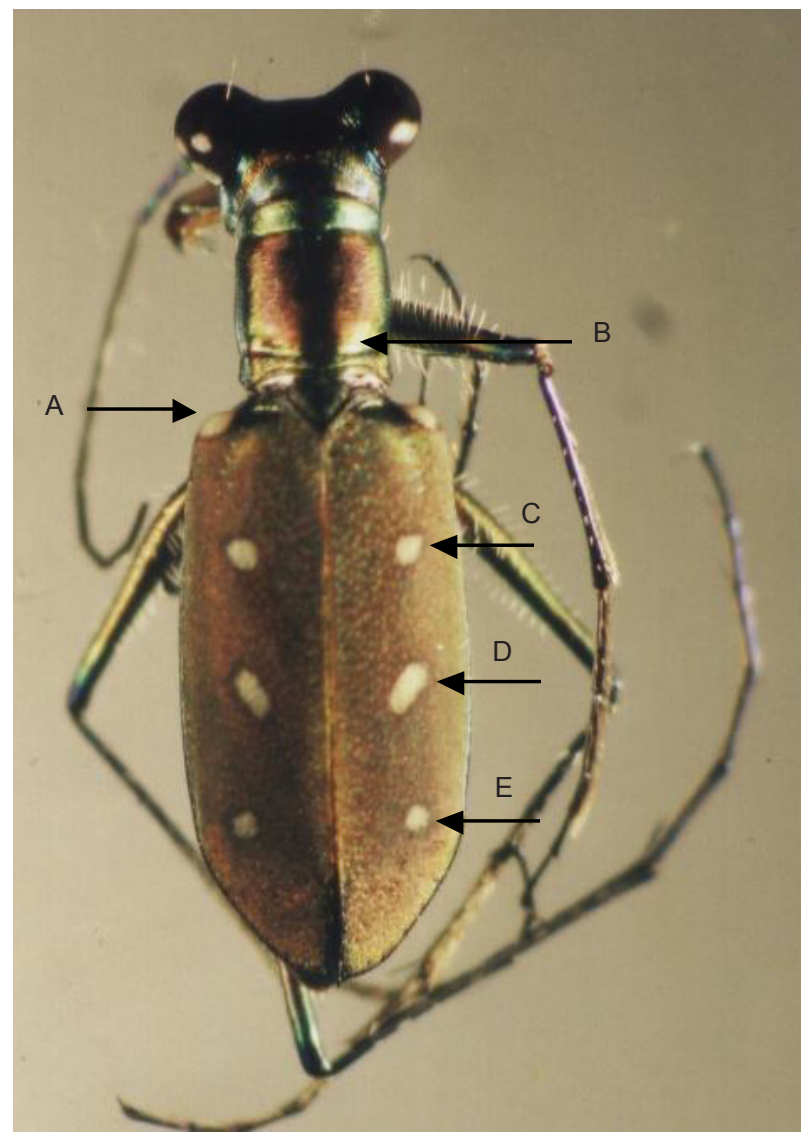

Image 3. Cicindela (Ifasina) willeyi Horn, 1904 female , habitus, dorsal view (total length $=9.2 \mathrm{~mm})(\times 10 \times 1.0)$ A - Elytral humeral spot; B - Pronotum; C - First elytral spot; D - Second elytral spot; E - Third elytral spot

Colombo matches the features observed in the specimens collected from Maha Oya (Dehi Owita) and Handapangoda sites.

Diagnosis: Cicindela (Ifasina) willeyi $\mathrm{H}$. closely resembles the other allied species $C$. (I.) waterhousei

Table 3. Morphometric parameters of Cicindela (Ifasina) willeyi Horn collected from Maha Oya (Dehi Owita) and Handapangoda

\begin{tabular}{cccc}
\hline Specimen No. & Body Length $(\mathbf{m m})$ & Body Weight $(\mathbf{m g})$ & Left Mandible Length $(\mathbf{m m})$ \\
\hline BMNH(E)703891 & 9.45 & 32.3 & 1.63 \\
BMNH(E)703898 & 8.68 & 23.4 & Damaged \\
BMNH(E)703899 & 9.35 & 27.8 & Damaged \\
BMNH(E)703900 & 9.40 & 31.2 & 1.88 \\
BMNH(E)703901 & 9.60 & 31.3 & Damaged \\
BMNH(E)703902 & 8.88 & 25.5 & Damaged \\
BMNH(E)703903 & 9.00 & 23.1 & Damaged \\
BMNH(E)703904 & 9.20 & 24.7 & 2.20 \\
\hline Average & $\mathbf{9 . 1 9 \pm 0 . 5 6}$ & $\mathbf{2 7 . 4 5 \pm 1 . 9 4}$ & $\mathbf{1 . 9 0 \pm 0 . 5 4}$ \\
\hline
\end{tabular}


Table 4. Climatic conditions at Maha Oya (Dehi Owita) and Handapangoda

\begin{tabular}{|l|l|l|}
\hline Parameter & $\begin{array}{l}\text { Maha Oya } \\
\text { (Dehi Owita) }\end{array}$ & Handapangoda \\
\hline Temperature & $32^{\circ} \mathrm{C}$ & $32^{\circ} \mathrm{C}$ \\
\hline Relative humidity & $65 \%$ & $65 \%$ \\
\hline Solar radiation & $132 \mathrm{~W} / \mathrm{m}^{2}$ & $126 \mathrm{~W} / \mathrm{m}^{2}$ \\
\hline Barometric pressure & $760 \mathrm{Hgmm}^{-1}$ & $760 \mathrm{Hgmm}^{-1}$ \\
\hline Wind speed & $0 \mathrm{~ms}^{-1}$ & $0 \mathrm{~ms}^{-1}$ \\
\hline Wind direction & South-West & South-West \\
\hline
\end{tabular}

Horn, C. (I.) dormeri Horn and C. (I.) ganglbaueri Horn that are also endemic to Sri Lanka. However, the species can be distinguished by the presence of an elytral humeral dot and three spots that lie medially in a line on elytra; more excavate forehead between the eyes; narrow, conical pronotum with a dorsal bulge that is undivided by a short medial line (Image 3 ).

Description: Body small with an average length
Table 5. Soil conditions at Maha Oya (Dehi Owita) and Handapangoda

\begin{tabular}{|l|l|l|}
\hline Parameter & $\begin{array}{l}\text { Maha Oya } \\
\text { (Dehi Owita) }\end{array}$ & Handapangoda \\
\hline Soil group & $\begin{array}{l}\text { Red-Yellow Podzolic } \\
\text { soil }\end{array}$ & $\begin{array}{l}\text { Red-Yellow } \\
\text { Podzolic soil }\end{array}$ \\
\hline Soil type & Sand & Sand \\
\hline Soil colour & $\begin{array}{l}\text { Yellowish-brown } \\
(10 Y R 5 / 6)\end{array}$ & $\begin{array}{l}\text { Dark yellowish- } \\
\text { brown (10YR4/6) }\end{array}$ \\
\hline Soil temperature & $28^{\circ} \mathrm{C}$ & $27^{\circ} \mathrm{C}$ \\
\hline Soil pH & 6.8 & 6.0 \\
\hline Soil moisture & $2.89 \%$ & $17.96 \%$ \\
\hline
\end{tabular}

of $9.19 \pm 0.56 \mathrm{~mm}$ and an average body weight of $27.45 \pm 1.94 \mathrm{mg}(\mathrm{n}=8)$ (Table 3$)$. Dorsal region of head, pronotum and base of eyes shiny copper green in colour. Elytra metallic brown with a humeral dot, and three spots medially in a line. Spots yellowishwhite in colour. First and third spot circular and small. Middle spot large, ovate or pear-shaped. Ventral side

DNA Barcode (consensus sequence of CO1 gene) of Cicindela (Ifasina) willeyi H. (GenBank Accession Number: HM600780)

\begin{abstract}
TTTGGGATAATTTCACATATTATCAGCCAAGAAAGAGGTAAAAAGGAAACATTTGGATCATTG GGYATAATTTACGCTATATTAGCAATTGGRTTATTAGGATTTGTAGTTTGAGCTCATCATATAT TTACTGTAGGAATAGATGTAGACACTCGRGCCTACTTCACCTCTGCCACTATAATTATTGCTGT ACCAACAGGYATTAAAATTTTTTCATGACTMGCCACACTTCATGGATCTCAAATTTCTTACAG ACCYTCTCTATTGTGAGCCTTGGGATTTGTATTCCTATTCACTGTGGGRGGYCTAACTGGRGTA GTATTAGCAAATTCATCAATTGATATTATCCTTCATGATACATATTATGTAGTTGCYCATTTTC ACTACGTTCTATCAATAGGRGCAGTATTCGCAATTATATCAGGATTTATCCAATGATTCCCATT ATTTACAGGATTAACTATGAACAATAGCTTRCTTAAAATTCAATTTATAATTATATTTGTGGGG GTTAATCTTACATTCTTCCCTCAACATTTCCTAGGATTAAGAGGGATACCTCGTCGGTACTCAG ACTACCCTGATGCTTATGTTTCATGAAATATYGTATCATCTATTGGCTCAACTATTTCGTTCAT TGGTGTATTAATGCTAATTTATATTATTTGAGAAAGATTTTCATCTCAACGCCTMGTRCTATTC CCTAATCAAATATCYACATCTATTGAATGATTCCAAAATATTCCCCCCGCTGAGCATAGTTACT CAGAACTT
\end{abstract}

Table 6. Historical change in distribution of Cicindela (Ifasina) willeyi with relevance to decline in geographic range.

\begin{tabular}{|c|c|c|c|c|c|c|c|c|}
\hline Species & $\begin{array}{l}\text { Past } \\
\text { Locations }\end{array}$ & $\begin{array}{l}\text { Appro- } \\
\text { ximate } \\
\text { Area }\left(\mathbf{k m}^{2}\right)\end{array}$ & $\begin{array}{l}\text { Present } \\
\text { Locations }\end{array}$ & $\begin{array}{l}\text { Appro- } \\
\text { ximate } \\
\text { Area } \\
\left(\mathrm{km}^{2}\right)\end{array}$ & $\begin{array}{l}\text { Decline in } \\
\text { Geographic } \\
\text { Range }\left(\mathrm{km}^{2}\right)\end{array}$ & $\begin{array}{l}\text { Past } \\
\text { Habitats }\end{array}$ & $\begin{array}{l}\text { Present } \\
\text { Habitats }\end{array}$ & Population Size \\
\hline $\begin{array}{l}\text { Cicindela } \\
\text { (Ifasina) } \\
\text { willeyi }\end{array}$ & $\begin{array}{l}\text { Central } \\
\text { Province; } \\
\text { Labugama, } \\
\text { Western } \\
\text { Province }\end{array}$ & $\begin{array}{l}5575 \\
8.5\end{array}$ & $\begin{array}{l}\text { Maha Oya, } \\
\text { Dehi Owita, } \\
\text { Sabaragamuwa } \\
\text { Province; } \\
\text { Handapangoda, } \\
\text { Western Province }\end{array}$ & $\begin{array}{l}17 \\
11\end{array}$ & 5555.5 & Unknown & $\begin{array}{l}\text { Riparian. } \\
\text { On the } \\
\text { sandy } \\
\text { banks } \\
\text { of river / } \\
\text { stream. }\end{array}$ & $\begin{array}{l}\text { Past - Unknown. } \\
\text { Maha Oya } 50 \text { beetles } \\
\text { were observed in the area. } \\
\text { Handapangoda } 10 \text { beetles } \\
\text { were observed in the area. }\end{array}$ \\
\hline
\end{tabular}


of body iridescent bluish-green with white setae. Labrum short, broad and brown in colour with eight or nine submarginal setae. Mandibles dark brown with left mandible having an average length of $1.90 \pm 0.54$ $\mathrm{mm}(\mathrm{n}=3)$. Pronotum with a medial dorsal bulge that is undivided by a medial line. Legs shiny blue-green in colour (Image 3).

Habitat of $\boldsymbol{C}$. (I.) willeyi: Beetles were found on a sandy bank at Maha Oya (Dehi Owita) which is a shallow stream found in the Sabaragamuwa Province. The periphery of the sandy bank consisted of shrub type vegetation of Gahala Colocasia esculenta, Bamboo Bambusa vulgaris and long grasses that provided shade to the habitat. Climatic and soil conditions of the site are given in Tables 4 and 5 .

The climatic and soil conditions at Handapangoda were more or less similar to that of Maha Oya (Dehi Owita) (Tables $4 \&$ 5). However, the beetles at Handapangoda were mainly found on the moist rocks on the sandy bank. Further, the habitat at Handapangoda was more better shaded than that at Maha Oya due to the large trees found on the bank.

Historical change in distribution of $C$. (I.) willeyi: The species has been reported from the Central Province of the island and Labugama, Western Province from as far back as 1904 (Horn 1904; Fowler 1912; Acciavatti \& Pearson 1989; collection of the National Museum of Colombo, Sri Lanka). However, it has not been studied thereafter, and although it's biology is well known, data on present distribution and habitat is lacking. According to the results of the current study, at present it occupies two habitats in Maha Oya (Dehi Owita) area and Handapangoda area. Investigations in the present study have further revealed that the species is absent from its former locations of Central Province and Labugama which have a geographical area of about $5583.5 \mathrm{~km}^{2}$ and is now restricted to an area of about $28 \mathrm{~km}^{2}$ in Maha Oya (Dehi Owita) and Handapangoda (Table 6).

Therefore, a loss of its present habitats where it is restricted in distribution may threaten the survival of the species and qualify it for a threatened category in the near future.

\section{DISCUSSION}

Cicindela (Ifasina) willeyi is an endemic tiger beetle species of Sri Lanka that was first described by Horn (1904) from the Central province of Sri Lanka, which was subsequently confirmed by Fowler (1912) and later by Acciavatti \& Pearson (1989). The National Museum of Colombo houses a specimen of the species collected from Labugama in the Western Province of the country. However, the present distribution of this endemic species has been uncertain and habitat characteristics and preferences were completely unknown. The present study reveals the species from Maha Oya (Dehi Owita) (Sabaragamuwa Province), and Handapangoda (Western Province), localities from which it had not been previously recorded. Further, extensive field work carried out in riparian habitats of Meewathura, Kandy; Ma Oya, Mawanella; Pundalu Oya, Kotmale Oya, Ramboda and Silverfalls, Nuwara Eliya (Central Province); and Labugama (Western Province) during the study period confirms the absence of the species from its previous localities of occurrence (Fig. 1). This knowledge on the past and present distribution of $C$. (I.) willeyi indicates the possibility of a historical change in the distributional range of the species.

Various factors including urbanization, increased intensity of recreational use of beaches, increased off-road vehicle traffic, conversion of the habitat to a dumping ground for automobile parts and construction material, increased vegetation encroachment that eliminates open areas and inundation of habitat caused by the construction of dams have been used to explain historical range changes in tiger beetles in the United States (Knisley \& Hill 1992; Kritsky et al. 1996; Knisley \& Fenster 2005; Pearson et al. 2006; Simmons 2007).

Therefore, it is possible that $C$. (I.) willeyi extirpated from the localities in the Central Province and Labugama, and inhabited the area in Handapangoda and Maha Oya (Dehi Owita). Even though, the reason for this is not precisely known, possible events of the past can be suggested.

The Mahaweli Development Programme was initiated in Sri Lanka in 1979 to fulfill the water requirements for agriculture, industrial and domestic use, develop hydropower and reduce flood peaks. As a result of this programme, four major reservoirs and 
dams, namely, Kotmale, Victoria, Randenigala and Rantambe were built along the main stem of the river that lies in the Central Province (Dayawansa 2008). Building of a dam is known to reduce and corrode soil and rock along the river as massive deposits of soil are left within the reservoir. The massive cobblestones, sand and crushed stones held back by the dam and the transformation of the once tortuous riverbank and riverway to a relatively straight river course results in the loss of habitat for many invertebrates who survive in this environment (Mao \& Zheng 2006). During reservoir filling the river and any associated wetland areas become inundated. Riffles, runs and pools of the river are lost beneath the rising waters, leading to the extirpation (or extinction) of habitat sensitive riverine species with tightly defined niche requirements (McAllister et al. 2001). Likewise, reservoir and dam construction along the Mahaweli River has resulted a considerable impact on river morphology and has inundated a vast area of land in the Central Province of the island. Aerial photographs obtained in 1985 and 2003, and topographical maps of the Survey Department of Sri Lanka, present encroachments towards the river across its floodplain area in Gohagoda, Central Province. Further, riparian areas in Peradeniya (Central Province) have changed to residential urban areas with considerable impacts of waste disposal (Dayawansa 2008).

It is also recorded that gold has been mined in the past from a concordant quartz reef in Central Sri Lanka (Nawaratne \& Dissanayake 2001), and several gemming grounds are located in Nuwara Eliya, Horton Plains, Hatton and Kandy (Herath 1984).

Therefore, it is strongly possible that $C$. (I.) willeyi went locally extinct from its historic sites in the Central Province of Sri Lanka and invaded the riparian habitats of Maha Oya (Dehi Owita) (Sabaragamuwa Province) and Handapangoda (Western Province) due to the unsuitability and loss of its former habitats. The presence of populations of the species at Maha Oya and Handapangoda, indicate the suitability of the habitat, climate and soil conditions of these locations.

Tiger beetles are known to prefer riverine habitats because of close proximity to food and water resources, safety from predators and reasonably low human disturbance (Bhargav \& Uniyal 2008). Shade of the habitat is used as an oviposition cue for many species and clusters of larval burrows were found near the bases of plants in Cicindela cursitans Le Conte, of Ohio Valley, United States (Brust et al. 2005).

Further, their activity and density are greatly influenced by daily temperature patterns (Schultz 1983), and adult tiger beetles are known to maintain internal body temperatures that are just below their lethal limits of $39^{\circ} \mathrm{C}$ (Pearson et al. 2006). A ground temperature ranging from $32-33{ }^{\circ} \mathrm{C}$ is known to be suitable for the activity and viability of tiger beetle populations, and a temperature of $34-35{ }^{\circ} \mathrm{C}$ determined the greatest number of matings in Cicindela (Cephalota) circumdata leonschaeferi Cassola (Eusebi et al. 1989).

Tiger beetles prefer sandy soils with minimal vegetation, where periodic disturbance by wind and water removes encroaching vegetation (Warren \& Buttner 2008). Colour patterns of adult tiger beetle species closely match the texture and hue of the soil substrate on which the species occurs (Pearson \& Vogler 2001), and matching the body colour with that of the soil plays an important role in predator evasion by reducing discovery (Morgan et al. 2000).

The habitats at Maha Oya (Dehi Owita) and Handapangoda were both riparian with sparse vegetation that consisted of shrubs. In Handapangoda, ferns and bamboo were found on the stream banks providing shade to the habitat while a similar habitat was also found at Maha Oya. Ground temperature were similar at both sites and were at $32^{\circ} \mathrm{C}$, while the soil temperature was $28^{\circ} \mathrm{C}$ at Maha Oya, and $27^{\circ} \mathrm{C}$ at Handapangoda. Both river banks consisted of soil with a sandy texture that was yellowish-brown at Maha Oya and dark yellowish-brown at Handapangoda. The colour of soil at both sites closely matched the colour of beetles, that were metallic brown dorsally with yellow-white maculations.

As C. (I.) willeyi is an endemic species with limited distribution and is consequently susceptible to local extinction, it is important that these habitats are identified and protected. At present, 99.5\% of its distributional range has declined (Table 6). We believe that the most important conservation priority of a country is the protection of areas which house large numbers of endemic species and communities found nowhere else in the world. This study presents first evidence and importance of Maha Oya (Dehi Owita) and Handapangoda locations, as harbouring the only populations of an endemic species of tiger beetles. In 
view of the current human use of all of these sites and habitats and the development pressures exerted on the wet zone of the country, conservation of these sites are essential for future survival of this species.

\section{REFERENCES}

Acciavatti, R.E. \& D.L. Pearson (1989). The Tiger Beetle Genus Cicindela (Coleoptera, Insecta) from the Indian Subcontinent. Annals of Carnegie Museum No. 58, Pensylvania, 353pp.

Bhargav, V.K. \& V.P. Uniyal (2008). Communal roosting of tiger beetles (Cicindelidae: Coleoptera) in the Shivalik Hills, Himachal Pradesh, India. Cicindela 40(1-2): 1-12.

Bierman, P. (2007). Management Solutions to Soil Limitations. State Master Gardener Conference, Department of Soil, Water and Climate, University of Minnesota, 9pp.

Brust, M., W.W. Hoback \& C.B. Knisley (2005). Biology, habitat preference, and larval description of Cicindela curtisans Leconte (Coleoptera: Carabidae: Cicindelinae). The Coleopterists Bulletin 59(3): 379-390.

Cassola, F. \& D.L. Pearson (2000). Global patterns of tiger beetle species richness (Coleoptera: Cicindelidae) their use in conservation planning. Biological Conservation 95: 197-208.

Dayawansa, N.D.K. (2008). Assessment of changing pattern of the river course and its impact on adjacent riparian areas highlighting the importance of multi-temporal remotely sensed data. Proceedings of the Asian Conference on Remote Sensing, Colombo, Sri Lanka.

Eusebi, M.P., L. Favilli \& S. Lovari (1989). Some abiotic factors affecting the activity and habitat choice of the tiger beetle Cephalota circumdata leonschaeferi (Cassola) (Coleoptera, Cicindelidae). Italian Journal of Zoology 56(2): 143-150.

Fowler, W.W. (1912). Fauna of British India including Ceylon and Burma (Coleoptera General Introduction and Cicindelidae and Paussidae). Today and Tomorrow's Printers and Publishers, New Delhi, 529pp.

Herath, J.W. (1984). Geology and Occurrence of Gems in Sri Lanka. The Journal of the National Science Council of Sri Lanka 12(2): 257-271.

Horn, W. (1904). The Cicindelidae of Ceylon. Spolia Zeylanica 2(5): 30-45.

Knisley, C.B. \& M.S. Fenster (2005). Apparent extinction of the tiger beetle, Cicindela hirticollis abrupta (Coleoptera: Carabidae: Cicindelinae). The Coleopterists Bulletin 59(4): 451-458.

Knisley, C.B. \& J.M. Hill (1992). Effects of habitat change from ecological succession and human impact on tiger beetles. Virginia Journal of Science 43(1): 133-142.

Kritsky, G., L. Horner, S. Reidel \& A.J. Savage (1996). The status of some tiger beetles (Coleoptera: Cicindelidae: Cicindela spp.) in Southern Ohio. Ohio Journal of Science
96(1): 29-30.

Mao, C. \& R. Zheng (2006). Analysis of impacts of dams on ecological environment of river ecosystem, pp. 11351142. In: Berga L., J.M. Boil, E. Bofill, J.C. De Cea, J.A.G. Perez, G. Manueco, J. Polimon, A. Soriano, J. Yague (eds.). Dams and Reservoirs, Societies and Environment in the $21^{\text {st }}$ Century. Taylor \& Francis Group, London, 1144pp.

McAllister, D.E., J.F. Craig, N. Davidson, S. Delany, \& M. Seddon (2001). Biodiversity impacts of large dams. IUCN/ UNEP/WCD Background Paper 1: 12-47.

Moorman, F.R. \& C.R. Panabokke (1961). Soils of Ceylon: a new approach to the identification and classification of the soils of Ceylon. Tropical Agriculture 117: 4-65.

Morgan, M., C.B. Knisley \& A.P. Vogler (2000). New taxonomic status of the endangered tiger beetle Cicindela limbata albissima (Coleoptera: Cicindelidae): Evidence from mtDNA. Ecology and Population Biology 93(5): 1108-1115.

Naviaux, R. (1984). Coleoptera, Cicindelidae. Les Cicindelés de Sri Lanka. Revue Scientifique Du Bourbonnais 57-80.

Nawaratne, C.B. \& C.B. Dissanayake (2001). Gold occurrences in Madagascar, South India and Sri Lanka: Significance of a possible Pan-African event. Gondwana Research 4(3): 367-375.

Pearson, D.L. \& F. Cassola (2005). A quantitative analysis of species descriptions of tiger beetles (Coleoptera: Cicindelidae), from 1758 to 2004, and notes about related developments in biodiversity studies. The Coleopterists Bulletin 59(2): 184-193.

Pearson, D.L. \& F. Cassola (2007). Are we doomed to repeat history? A model of the past using tiger beetles (Coleoptera: Cicindelidae) and conservation biology to anticipate the future. Journal of Insect Conservation 11: 47-59.

Pearson, D.L. \& A.P. Vogler (2001). Tiger Beetles: The Diversity, Ecology and Evolution of the Cicindelidae. Cornell University Press, Ithaca, New York, 333pp.

Pearson, D.L. (1988). Biology of tiger beetles. Annual Review of Entomology 33: 123-147.

Pearson, D.L., C.B. Knisley \& C.J. Kazilek (2006). A Field Guide to the Tiger Beetles of the United State and Canada: Identification, Natural History and Distribution of the Cicindelidae. Oxford University Press, Oxford, New York, $227 \mathrm{pp}$.

Pearson, D.L. \& S.A. Juliano (1993). Evidence for the influence of historical processes in co-occurrence and diversity of tiger beetle species, pp. 194-202. In: Ricklefs, R.E. \& D. Schulter (eds.). Species Diversity in Ecological Communities. Chicago University Press, Chicago, USA.

Satoh, A. \& M. Hori (2004). Interpopulation differences in the mandible size of the coastal tiger beetle Lophyridia angulata associated with different sympatric species. Entomological Science 7: 211-217.

Schultz, T.D. (1983). Opportunistic foraging of western kingbirds on aggregations of tiger beetles. Auk 100: 496497.

Simon, C., F. Frati, A. Beckenbach, B. Crespi, H. Liu \& P. 
Flock (1994). Evolution, weighting and phylogenetic utility of mitochondrial gene sequences and a compilation of conserved polymerase chain reaction primers. Annals of the Entomological Society of America 87: 651-701.

Simmons, T. (2007). Natural Heritage \& Endangered Species Program. Division of Fisheries \& Wildlife, Westborough, MA.

Tennent, J.E. (1860). Ceylon: An Account of the Island Physical, Historical and Topographical with Notices of its Natural History, Antiquities and Productions. Longman and Roberts, London, 631pp.

Warren, S.D. \& R. Buttner (2008). Active military training areas as refugia for disturbance-dependent endangered insects. Journal of Insect Conservation 12: 671-676.
Author Details: Dr. Chandima Dangalle is a senior lecturer in Zoology. Her expertise lies in the fields of entomology and molecular biology. Her research focuses on collecting baseline data on the distribution and habitat preferences of tiger beetles in Sri Lanka and in evolution and phylogeny of the species. Dr. Dangalle conducted her PhD in the Department of Zoology, University of Colombo, Sri Lanka and Department of Entomology, Natural History Museum, London, United Kingdom.

Dr. Nirmalie Pallewatta is a senior lecturer and the current head of the Department of Zoology, University of Colombo, Sri Lanka. A zoologist by training Dr. Pallewatta received her Ph.D. in 1986 from the Imperial College of Science, Technology and Medicine at the University of London, U.K.

Dr. Alfried Vogler works on the molecular systematics of Coleoptera. He has a joint position at the Natural History Museum and at Imperial College, London, U.K. Together with $\mathrm{PhD}$ students and postdocs, he is currently studying basal relationships of Scarabaeinae and Aphodiinae. He is also interested in the factors determining the composition of dung beetle communities and the effect of species interactions on the evolution of ecomorphological diversity.

Acknowledgements: We wish to thank the Department of Wildlife Conservation, Ministry of Environment, Sri Lanka for providing permits necessary for field work and export of specimens. We are grateful to Prof. Nimal Dangalle, Department of Geography, University of Kelaniya, Sri Lanka for his assistance in the preparation of maps and locational lists. This work has been supported by grant number RG/2003/ZOO/01 from the National Science Foundation of Sri Lanka. 